\title{
ГЕНДЕРНІ ОСОБЛИВОСТІ ПРОМОВ АМЕРИКАНСЬКИХ ПОЛІТИКІВ В УКРАЇНСЬКОМУ ПЕРЕКЛАДІ
}

\author{
Медвідь О. М., Чігрін Г. А.
}

\section{ВСТУП}

Політичні комунікації є невід'ємною частиною соціального життя XXI сторіччя, а політичний дискурс має потенціал програмувати свідомість і поведінку людей, тому об'єктом вивчення у статті $€$ політична промова. Дослідження має комунікативно-прагматичний характер і покликане не тільки продемонструвати особливості різних видів комунікативних стратегій і тактик, але і пояснити, як виникає це різноманіття, що ускладнює виникнення продуктивних соціальних комунікацій, спираючись на гендерний аспект у спічах політичних лідерів. Під порівняльний аналіз підпадають індивідуальні мовленнєві здібності окремих політиків як предиктори успішних комунікацій із суспільством.

Актуальність цього дослідження визначається тим, що в ньому висвітлюються особливості застосування перекладацьких прийомів у відтворенні засобів реалізації стратегії театральності найсучасніших зразків спічів американських політичних діячів українською мовою та акцентується увага на гендерному аспекті зазначеної проблеми.

Метою роботи є комплексний аналіз засобів реалізації стратегії театральності у виступах сучасних політичних діячів США та зіставлення лексико-стилістичного експресивного навантаження текстів оригіналу (англійською) та перекладу (українською) з урахуванням гендерного підходу.

Для досягнення поставленої мети в дослідженні визначені такі завдання, як: узагальнення й конкретизація теоретичних засад стратегії театральності американського політичного дискурсу; дослідження основних закономірностей використання стратегії театральності крізь призму гендеру; визначення основних шляхів відтворення у перекладі стилістичних та лексичних особливостей реалізації цієї стратегії 3 урахуванням гендерного аспекту; визначення найоптимальніших засобів збереження емотивності і прагматики тексту оригіналу.

Предметом вивчення $є$ перекладацькі прийоми відтворення гендерних маркерів у спічах сучасних американських політичних діячів 
з урахуванням емотивних лексичних та стилістичних засобів реалізації стратегії театральності в перекладі українською мовою.

матеріал дослідження становлять відеозаписи виступів політичних діячів, статті в Інтернет-виданнях, дописи у соціальних мережах, скрипти теледебатів під час передвиборчих кампаній, інавгураційних промов від Демократичної та Республіканської партій США (2012-2020 рр.), узяті з Інтернет-сайтів відомих видавництв та аналітичних організацій.

Методологічна база дослідження грунтується на комунікативнопрагматичній парадигмі дослідження мови, напрацьованій українськими та зарубіжними вченими, що сприяє проведенню аналізу стратегії театральності та особливостей іiі реалізації українською мовою шляхом застосування комплексу перекладацьких прийомів. Зокрема, дослідженням політичного дискурсу як особливої форми спілкування, вивченням механізмів взаємодії мови, влади та суспільства, описом вербальних засобів маніпуляції свідомістю громадян та вивченням впливу гендерного аспекту політичних виступів на процес перекладу політичного дискурсу займалися науковці: у галузі дискурсології (П. Серіо, 1999; О. Шейгал, 2000; А. Бєлова, 2004; В. Карасик, 2010), лінгвопрагматики (І. Шевченко та О. Морозова, 2005; Л. Безугла, 2007; I. Сусов, 2009; І. Фролова, 2009; Ф. Бацевич, 2010), теорії мовленнєвої діяльності (О. Леонтьєв, 2003; В. Різун, 2005), гендерних аспектів перекладу (А. Маркович, 1998; О. Медвідь, 2009; О. Попова, 2014) та ін.

Комплексний аналіз публічної промови в межах політичного дискурсу передбачає інтегроване застосування таких наукових методів, як: 1) метод вибірки - для формування емпіричного матеріалу; 2) дескриптивний метод - для узагальнення та інтерпретації мовленнєвого матеріалу; 3) методи аналізу та синтезу - для систематизації та упорядкування матеріалів дослідження; 4) метод контентного аналізу - для визначення мовленнєвих тактик і стратегій; 6) метод зіставного аналізу - для аналізу спільних та відмінних гендерно зумовлених рис у використанні мовленнєвих тактик різними політиками США; 7) перекладацький аналіз - для пошуку еквівалентних відповідників у тексті перекладу.

\section{1. Дискусія і результати}

Політичне мислення, комунікативна активність у політичній сфері і мова завжди перебувають у тісному взаємозв'язку, що підвищує інтерес до політичного дискурсу як до об'єкта міждисциплінарних досліджень. Однак в останні десятиліття ця галузь знань привертає все більше уваги лінгвістів. Мова в політиці виконує декілька функцій, але однією 3 ключових залишається персуазивна (регулювання поведінки 
та формування світогляду громадян). Це пов'язано з тим, що учасники політичної комунікації мають чіткі суспільно-політичні погляди, а з цього витікає, що обмін інформацією між сторонами завжди має інтенційний характер ${ }^{1}$.

Отже, одним із найбільш актуальних завдань політичної лінгвістики $€$ вивчення механізмів реалізації персуазивної функції політичного дискурсу, що передбачає дослідження здатності мовних одиниць впливати на цільову аудиторію, спонукаючи іiі до певних дій ${ }^{2}$. У межах політичного дискурсу цей напрям реалізується як вивчення механізмів реалізації експресивних засобів у різних стратегіях і тактиках, що вимагає комплексного дослідження текстів політичних спічів у площині взаємодії лексичного, синтаксичного, морфологічного та стилістичного мовних рівнів.

Останніми роками суспільство спостерігає посилення експресивності політичних виступів через актуалізацію стратегії театральності. Така тенденція зумовлена прагненням маніпуляції та структуризації суспільства і бажанням політичних лідерів знайти якомога більше прихильників своїх ідей. Політичний процес - це набір певних дій, що відтворюються політичними «акторами», спрямований на формування політичних та соціальних конструктів у свідомості жителів певної країни. Оскільки спектр адресатів політичної комунікації $\epsilon$ досить широким (за демографічними, інтелектуальними, соціальними та іншими показниками), застосування стратегії театральності у виступах американських політиків вимагає від них як адресантів інформації уваги до найменших дрібниць на всіх мовних рівнях.

Театральність політичного дискурсу передбачає наявність політиків (акторів) і народних мас (глядачів), причому присутність адресатаспостерігача безпосередньо впливає на поведінку політика, примушує його дотримуватися певної мовної поведінки і вигідної стратегії комунікації та створення власного іміджу на потребу дня ${ }^{3}$. Однак імідж політика, його комунікативна поведінка та засоби реалізації комунікативної стратегії $\epsilon$ гендерно зумовленими у сучасному суспільстві.

1 Benoit W.L., Blaney J.R., Pier P.M. Campaign'96: A functional analysis of acclaiming, attacking, and defending. New York : Praeger. 1998. 342 p.

${ }^{2}$ Маркович А.А. Аргументативная коммуникация. Методология исследования политического дискурса: Актуальные проблемы содержательного анализа общественно-политических текстов : сб. науч. трудов / под общ. ред. И.Ф. Ухвановой-Шмыговой. Минск : Белгосуниверситет. 1998. Вып. 1. С. 144-150.

3 Шестопал О.Г. Театральність як перцептивна категорія у контексті сучасних міждисциплінарних досліджень. Літературознавчі студіï. 2013. № 37(2). С. 436-442. 
Гендер як соціокультурна категорія регулярно відтворюється у структурах мовної свідомості індивіда під час реальної дискурсивної та інтерактивної взаємодії, зумовленої метаконтекстом картини світу певної лінгвоетнокультури, макроконтекстом соціокультурних норм та безпосередньо мікроконтекстом конкретної міжособистісної взаємодії. Гендерна належність промовців $\epsilon$ інтегральною складовою частиною мовної особистості, комплексом біологічних та соціокультурних характеристик і актуалізується у мовленні в кожній окремій ситуації спілкування ${ }^{4}$, на що треба звертати особливу увагу під час перекладу, враховуючи не тільки різницю в морфолого-синтаксичній структурі мов, що досліджуються (англійська/українська), але і у функціональносемантичному i стилістичному навантаженні вживаних лексичних одиниць.

\section{2. Лексичні трансформації під час перекладу}

На рівні семантики викликають інтерес особливості вживання лексем 3 різним ступенем емоційного навантаження - маркерів, що безпосередньо кваліфікують чоловіка та жінку, їхні атрибути та дії. Слід відзначити, що в рамках стратегії театральності американського політичного дискурсу широкої популяризації набули лексичні інтенсифікатори та оцінна лексика як серед чоловіків-, так і жінокполітиків ${ }^{5}$.

У процесі аналізу політичних промов встановлено, що жінкиполітики досягають ефекту театральності за рахунок використання модальних слів і конструкцій, у семантичній структурі яких основу становить сема «безсумнівності та впевненості». Посилення оцінного значення у їх висловлюваннях може досягатися шляхом:

1) вживання модальних слів і словосполучень зі значенням «безсумнівно» (no doubt, unquestionably, absolutely тощо):

I absolutely support a two-state solution because it is the best way to ensure the existence of a Jewish, democratic, and secure Israel (Kamala Harris). / Я повністю підтримую рішення про існування двох держав, оскільки ие найкращий спосіб забезпечити існування єврейського, демократичного та безпечного Ізраїлю (переклад - авт.).

Словосполучення “a two-state solution" перекладено як «рішення про існування двох держав» 3 метою полегшення сприйняття

4 Маслова Ю.П. Особливості розвитку гендерних лінгвістичних досліджень в Україні та за кордоном. Наукові записки Національного університету «Острозька академія». Серія Філологічна. 2015. Вип. 57. С. 100-105.

5 Приходько Г.І. Лексико-граматичні інтенсифікатори оцінних структур. Науковий вісник ДДПУ імені І. Франка. 2017. С 154-158. 
інформації для україномовного реципієнта, не знайомого з політичною ситуацією в Ізраїлі. Ми не використали прийом уточнення «рішення про існування двох держав - Палестини та Ізраїлю» для уникнення зайвої тавтології в реченні.

2) застосування модальних слів із значенням «значно» (incredibly, really, deeply тощо):

I am deeply troubled by the alarming reports of widespread human rights abuses against Uyghurs and other Muslim Chinese citizens (Kirsten Gillibrand). / Я глибоко схвильована тривожними повідомленнями про численні випадки порушення прав людини стосовно уйгурів та інших громадян Китаю, що сповідують мусульманство (переклад - авт.).

Вираз "widespread human rights abuses" перекладено «випадки порушення прав людини», використовуючи перекладацьку трансформацію додавання (іменник «випадки») 3 метою адаптації до системи української мови. Прикметник “alarming” лише підсилює настороженість політика стосовно ситуації, яка склалася, тому задля збереження прагматичної цінності висловлювання його переклад здійснено шляхом синонімічного перекладу.

3) употужнення ефекту театральності за допомогою прислівників зі значенням «правдащ, «істиннощ (honestly, frankly, sincerely тощо):

I frankly believe that it is contrary to everything that we have symbolically and actually said we stand for (Kamala Harris). / Я щиро вірю, що цее суперечить усьому, за щчо ми насправді пообіияли стояти горою (переклад-наш).

У процесі перекладу цього речення нами застосовано трансформацію заміни словосполучення “is contrary" дієсловом «суперечить». Крім того, аби зберегти емоційне навантаження $i$ зміст висловлювання, використано прийом компенсаиії: фразу "wе have symbolically and actually said we stand for" перекладено «за щзо ми насправді пообіияли стояти горою». Таким чином, ми уникли слова «символічно», проте зберегли символізачію через метафору «стояти горою». На наму думку, така заміна $\epsilon$ виправданою, адже фразеологізм «стояти горою» $є$ легким для сприйняття $i$ досить символічним для україномовного реципієнта.

Використання вищевказаних інтенсифікаторів у політичних спічах жінок-політиків робить їхні виступи більш емоційними та експресивними та створює ілюзію глибокого переживання за життя суспільства та долю держави.

Своєю чергою чоловікам-політикам більш характерне вживання великої кількості прикметників, які підсилюють значення іменників.

China's oppression of the Uighurs including the detention of a massive number in internment camps is a gross violation of their human rights. 
A fundamental component of American foreign policy must be to promote human rights and democracy (Steve Bullock). / Утискання уйгурів з боку Китаю, включаючи затримання величезної кількості в таборах для інтернацій, є грубим порушенням їхніх прав. Основним компонентом американської зовнішньої політики має бути просування прав людини та демократії (переклад - авт.).

Крім того, мовлення чоловіків-політиків насичене конкретними даними, датами, відсотками тощо. Чоловіки прагнуть підсилити свої аргументативні позиції за рахунок статистики.

The nearly 800.000 DACA-recipients, who are currently working in the United States or attending a university or college, should not be penalized for the gridlock in Washington (Steve Bullock). / За затори у Вашингтоні не варто карати близько 800000 громадян, які потрапили під дію програми DACA (заборона на депортацію нелегальних мігрантів, які прибули в США до настання свого повноліття), $i$ зараз працюють у Сполучених Штатах або відвідують університет чи коледж (переклад - авт.).

У цьому випадку застосовано перекладацький прийом транспозиції 3 метою адаптації інформації для україномовного читача. Абревіатуру $D A C A$ ми вирішили за доцільне залишити без змін, але додатково використали прийом описового перекладу в коментарі «заборона на депортацію нелегальних мігрантів, які прибули в США до настання свого повноліття», оскільки прямого відповідника цього поняття в українській мові не існує.

На противагу конкретиці чоловіків-політиків для підкріплення своєї комунікативної позиції жінки-політики часто звертаються до художньої аргументації, цитуючи визнаних авторів.

John F. Kennedy once said, "Ask not what your country can do for you, but what you can do for your country." We must heed his call to action today, at this critical time in our history (Tulsi Gabbard). I Джон Ф. Кеннеді одного разу сказав: «Запитайте себе не про те, що ваша краӥна може зробити для вас, а про те, що ви можете зробити для своєї країни». Ми повинні прислухатися до його заклику до дії сьогодні, у иі критичні для нашої історії часи (переклад - наш).

Посилання на слова Джона Ф. Кеннеді покликане спровокувати у реципієнтів почуття ностальгії та викликати асоціацію, що все, що не вдалося реалізувати славнозвісному президенту за такий короткий термін його перебування на посаді, буде реалізовано Тулсі Габбард. 3 метою збереження експресивності в українському варіанті та передачі серйозності посилу тексту оригіналу звертання “ask" перекладено шляхом додавання займенника «себе». Переклад словосполучення “critical time” виконано з використанням прийому калькування, проте задля збереження експресивності тексту змінено форму однини слова “time” на форму множини - «часи». 
Аналіз спічів американських політиків дає підстави вважати, що найбільшою відмінністю в гендерному аспекті $\epsilon$ те, що жінки-політики не бояться звертатися до емоцій та почуттів реципієнтів, при цьому не приховуючи власних.

Love is not just a feeling. It is a powerful force that drives us to act, to put service above self (Tulsi Gabbard). / Любов - ие не просто почуття. Це потужна сила, яка змушує нас діяти, ставити обов'язки перед державою вище власних (переклад - авт.).

Загалом, жінки більш чутливі до проблем і нещасть людей. Тому гендерно зумовлені характеристики мови проявляються у спробі створення образу жінки-лідера, яка служить своїй країні і виступає в ролі матері всієї нації. Яскравим підтвердженням цих слів є фрагмент промови тієї ж Тулсі Габбард.

Just over a year ago, the people of Hawaii and our country thought we were under nuclear attack. College students frantically ran across campus trying to find shelter. A father lowered his little girl into a man-hole to try to keep her safe. Families piled their kids into the car, driving to the mountains, looking for a cave to shelter in. A mother, in her bathtub, cowering in fear with her child. A father having to choose which of his children to spend the last minutes of his life with (Tulsi Gabbard). / Tpoxu більше року тому жителі Гаваїв та всієї намої країни отримали повідомлення про ядерну атаку. Студенти коледжу відчайдушно бігали по кампусу, намагаючись знайти прихисток. Батько опустив дівчинку в нору, намагаючись врятувати ій життя. Сім'ї забирали своїх дітей у машини, їхали в гори, шукали печери, в яких можна було б заховатися. Мати, яка від страху притискала до грудей свого малюка у ванній. Батько, якому треба було вибирати, з ким із своїх дітей провести останні хвилини життя (переклад - авт.).

У цій промові Тулсі Габбард показує себе в ролі не лише відповідального політика, а й громадянина, відданого своїй країні, що імплікується шляхом використання займенника our у фразі “реople of Hawaii and our country” і потребує підсилення соціополітичної значущості через додавання займенника всієї в перекладі «жителі Гаваїв та всієї нашої країни», що вмотивовано бажанням викликати в реципієнта відчуття єдності Гаваїв і США. Використання іменників «батько», «сім'я», «діти», «мати», «малюк», що є дуже характерним для жіночого політичного дискурсу в рамках реалізації стратегії театральності, покликане торкнутися почуттів кожного слухача, адже ніщо не хвилює людину більше, ніж негаразди у сім'ї. Слово “child” у реченні "A mother, in her bathtub, cowering in fear with her child" перекладено шляхом використання синоніма - «малюка». Ми вважаємо такий підхід доцільним, оскільки це дало змогу уникнути тавтології у подальшому. 
Проте, аби визначити і зміцнити свою позицію на політичній арені, а також самоствердитися в цій ролі, жінкам-політикам постійно доводиться боротися за утвердження свого статусу, за своє право бути рівноправним учасником політичного життя країни. Це призводить до маскулінізації у їхніх висловлюваннях.

Love should not be mistaken for weakness. There is no force more powerful than love. I am proud to serve our country as a soldier. I'm a Major in the Army National Guard where I've served for the last 15 years (Tulsi Gabbard). / Любов не потрібно плутати зі слабкістю. У світі немає нічого сильнішого за любов. Я з гордістю стверджую, шо я солдат американської армії. Я майор Національної гвардії армії США, де я служу останні 15 років (переклад - авт.).

Своїми словами "Love should not be mistaken for weakness" Тулсі Габбард підкреслює, що, незважаючи на те, що вона жінка, якій властиві почуття і емоції, це не заважає бути їй сильною та рішучою. Аналізуючи переклад речення "I am proud to serve our country as a soldier” - «Я з гордістю стверджую, щзо я солдат американської армії», варто підкреслити, що для полегшення сприйняття україномовного реципієнта, ми використали декілька трансформацій, а саме додавання дієслова «стверджувати» (для посилення емотивності) та смислового розвитку - "our country" ми замінили на «американська армія», враховуючи катафоричні контекстуальні відношення

Своєю чергою аналіз політичних спічів показав, що для мовлення чоловіків-політиків характерним $\epsilon$ вживання великої кількості дієслів. Це зумовлене їхнім бажанням показати готовність служити країні не словом, а ділом.

Our strategic goal will be to support the evolution of a democratic, unified, sovereign Ukraine and to force the Kremlin to pay a price for its unrelenting attacks on the international order (Joe Biden). / Hama стратегічна мета - підтримати еволючію демократичної, єдиної, суверенної України та змусити Кремль заплатити ціну за свої невблаганні напади на міжнародний порядок (переклад - авт.).

У своєму висловлюванні Джо Байден використовує дієслова «nідтримати», «змусити», «заплатити», на яких і базується основний зміст висловлювання. Словосполучення “international order" перекладено калькуванням, щоб не загубити навіть відтінку смислу.

\section{3. Стилістичні трансформації у перекладі}

Крім того, в процесі дослідження було встановлено, що в межах реалізації стратегії театральності особливої уваги заслуговують характерні риси використання стилістичних засобів чоловіками- та

6 Клименко I.M., Зоренко I.C. Лексичні трансформації у передачі англійської політичної термінології українською мовою. Філологічні студії. 2012. Вип. 8. С. 84-90. 
жінками-кандидатами на пост президента США та шляхи їх відтворення в українському перекладі.

Як доводить дослідження, метафоризація слів або словосполучень особливо сприяє експресивному забарвленню спічів жінок-політиків, завдяки чому вони ефективніше впливають на свідомість слухача/читача, активізують його емоційно-почуттєву сферу ${ }^{7}$.

President Trump has consistently turned a blind eye to these abuses in hopes of earning a 'win' in his trade war, all to no avail (Kamala Harris). I Президент Трамп постійно закривав очі на ијі зловживання, сподіваючись отримати «виграш» у свойй торговій війні, проте все без толку (переклад-авт.).

Аналізуючи висловлювання Камали Харpic, фразеологізм "turned a blind eye” ми переклали українським еквівалентом «закривав очі», для передачі значення "all to no avail” ми підібрали еквівалент - «без толку», а для підсилення експресивності висловлювання застосовано перекладацький прийом додавання «проте все без толку».

Additionally, we must flood Congress with calls - so memorize the number (202) 224-3121 (Kamala Harris). / Крім того, ми повинні безперестанку дзвонити в Конгрес, тому запам'ятайте номер (202) 224-3121 (переклад-авт.).

Передачу значення метафори “flood Congress with calls” здійснено за допомогою перекладацького прийому контекстуальної заміни метафори прислівником із значенням непереривності «безперестанку». Як варіант перекладу ми розглядали «засипати дзвінками», проте таке словосполучення не $\epsilon$ характерним для української мови. Передача метафор та фразеологічних одиниць становить труднощі для перекладача, особливо якщо одиниця оригіналу не має відповідників у мові перекладу.

Характерним стилістичним засобом політичних виступів $є$ також перифраз. Варто зазначити, що цей засіб набув ширшого використання у спічах жінок-політиків. Він використовується у двох функціях: або замінити грубе, образливе повідомлення, або навпаки, 3 метою дискредитації та висловлення зневаги до об'єкта ${ }^{8}$.

And unlike the current occupant of the White House, I will consistently stand up to Putin in defense of democratic values, human rights, and the international rule of law (Kamala Harris). I I на відміну від нинішнього окупанта Білого Дому, я буду незмінно протистояти Путіну в захисті

${ }^{7}$ Charteris-Black J. Analysing Political Speeches: Rhetoric, Discourse and Metaphor. Palgrave Macmillan, 2013. 296 p.

Щеголєва Т.Л. Використання та переклад стилістичних засобів в американському політичному дискурсі. Вісник Черкаського університету. Серія: Філологічні науки. 2015. Вип. 7. С. 95-100. 
демократичних иінностей, прав людини та міжнародного правопорядку (переклад-авт.).

Передачу значення перифразу "current occupant of the White House" здійснено шляхом калькування "нинішнього окупанта Білого Дому» з метою збереження образності висловлювання. Використовуючи прикметник "current", Камала Харріс підкреслює тимчасовість правління Дональда Трампа та неминучість змін у Білому Домі. А іменник "осcupant” підкреслює небажання чинного президента покидати свій пост.

Своєю чергою експресивність спічів чоловіків-політиків досягається шляхом використання великої кількості епітетів.

This could be accompanied with corresponding measures on sanctions relief, as well as substantive progress on building a lasting peace regime and normalizing relations (Pete Buttigieg). / Це може супроводжуватися відповідними заходами щодо зняття санкиій, а також суттєвим прогресом у створенні стійкого мирного режиму та нормалізаиії відносин (переклад - авт.).

Переклад епітетів зазвичай не створює труднощів для перекладача, позаяк вони здебільшого перекладаються словниковими відповідниками: “corresponding” - «відповідний», “substantive” «суттевий», "lasting”- «стійкий».

Персоніфікація як стилістичний засіб особливо часто застосовується в політичному дискурсі стосовно назви країни. Дослідження виявило, що американські політики обох статей однаковою мірою використовують цей засіб у своїх спічах:

America can help solve these problems, but only if we restore our leadership and build up the rules-based world order (Joe Sestak). / Америка може допомогти вирішити ці проблеми, але тільки якщо ми відновимо своє лідерство та створимо світовий порядок, заснований на правилах (переклад-наш).

Так Джо Сестак персоніфікує образ Америки. Персоніфікація образу Америки створює враження єдності нації, де кожен громадянин має цінність та значення для країни. Цій саме меті підпорядковане вживання займенників we та our.

Проте найбільш поширеними стилістичними засобами реалізації стратегії театральності $\epsilon$ паралельні конструкції у формі досить простих тавтологічних повторів, які використовуються для реалізації функції виділення головної думки чи ідеї. Цей прийом характерний як для спічів чоловіків, так і для жінок-політиків.

We must stand up, and fight for the soul of our country. Stand up against big Wall Street banks who gamble with our money and our future. Stand up against overreaching intel agencies and big tech companies who take away our civil liberties and freedoms in the name of national security and corporate greed. Stand up against those who pollute our land, our water, and our oceans. Stand 
up against those who perpetuate bigotry, hatred and violence against our brothers and sisters because of their race, religion, or sexual orientation (Tulsi Gabbard). / Ми повинні встати і боротися за душу нашої краӥни. Встати проти великих банків на Уолл-стріт, які грають за наші гроші та наше майбутнє. Встати проти незліченних розвідувальних агентств та великих технологічних компаній, які порушують наші громадянські права та свободи в ім'я наиіональної безпеки та корпоративної жадібності. Встати проти тих, хто забруднює нашу землю, нашу воду та океани. Встати проти тих, хто увічнює фанатизм, ненависть та насильство стосовно наших братів і сестер через їхню расу, релігію чи сексуальну орієнтаиію (переклад - авт.).

Щоб передати рішучість політика та експресивність висловлювання, переклад ключової фрази "stand up" здійснено шляхом підбору прямого відповідника - «встати». Повторюючи цей заклик, Кристен Джилібранд концентрує увагу реципієнта на прогалинах у політичній системі, з якими не хоче боротися чинна влада.

That is why rather than warmly greet Putin in confidential conversations, or weigh his assertions above U.S. intelligence assessments, I would continue a policy of sanctions aimed at the group of Russian leaders who have undermined Ukraine's democracy, security and territorial integrity, and closely coordinate our policy with our European allies to deepen their impact (Kirsten Gillibrand). / Ось чому, замість того, щоб сердечно щебетати з Путіним під час конфіденційних розмов, чи зважувати його твердження з даними американської розвідки, я б продовжила політику санкиій, спрямованих на групу російських лідерів, які підірвали демократію, безпеку та територіальну иілісність України, та тісно координувала б наму політику з європейськими союзниками США з метою поглиблення їх впливу (переклад - авт.).

Іронія як засіб мовного впливу вважається дієвим способом дискредитації опонента. Переклад іронії українською мовою становить певні труднощі для перекладача, це пов'язано з бажанням зберегти образність та висміювальний характер. Тому передачу значення "warmly greet" здійснено за допомогою контекстуальної заміни "сердечно щебетати».

\section{ВИСНОВКИ}

Комплексний лінгвістичний аналіз політичних виступів відомих американських політиків встановив, що однією 3 ключових комунікативних стратегій, що актуалізується під час передвиборчої кампанії, є стратегія театральності, яка реалізується через певну акторську гру політиків на публіку-електорат. Як правило, такий політичний перформанс розігрується, з одного боку, для позитивного позиціонування одного політика, а 3 іншого - для створення негативного іміджу опонента. Зокрема, увага нашого дослідження 
фокусувалася на виявленні закономірностей функціювання стратегії театральності в політичному дискурсі США, проаналізовані спільні та відмінні риси у реалізації стратегії театральності політиками крізь призму гендеру та виявлені особливості їх передачі українською мовою. В процесі аналізу доведено, що принципових відмінностей на морфологічному та синтаксичному рівнях у мовленні жінок та чоловіків-політиків не існує. Проте на лексичному та стилістичному рівнях прослідковуються певні тенденції у наданні переваги відповідним мовним формам політиками обох статей.

У промовах жінок-політиків на противагу чоловікам-політикам міститься більша кількість лексико-стилістичних засобів мовлення. Жінки прагнуть зробити свої промови привабливими, красномовними, добре структурованими і граматично побудованими; тоді як мовлення чоловіків-політиків характеризується меншою кількістю стилістичних засобів, вони намагаються донести інформацію зрозумілою і простою мовою. До того ж проведене дослідження дало можливість зробити висновок, що не існує сталих універсальних методів відтворення лексико-стилістичних засобів реалізації стратегії театральності в політичних спічах, оскільки мова політики є динамічною, реагує на зміни у суспільстві і його мовленнєвому процесі, а тому характеризується розширенням та поповненням лексикону, що становить складність для перекладача і потребує аналітичного, комплексного, синергетичного підходу до процесу перекладу політичного дискурсу.

Процес дослідження політичної комунікації через вивчення різних форм політичного дискурсу має міждисциплінарний характер, тому що він корелює з такими галузями знань, як соціологія, політологія, психологія, філософія, що вивчають аспекти соціальних комунікацій i ïx вплив на сучасні тенденції соціального пізнання та розвиток суспільства загалом, що може слугувати базою наукових студій у перспективі.

\section{АНОТАЦІЯ}

У статті проаналізовано засоби реалізації стратегії театральності у спічах американських політичних діячів на лексико-стилістичному рівні та способи їх передачі українською мовою. Наголошено на необхідності збереження цих засобів у перекладі для найповнішого відтворення мовної особистості політика. Виділено та описано основні гендерні відмінності у використанні засобів реалізації стратегії театральності, охарактеризовано особливості перекладацьких трансформацій при цьому в україномовному варіанті, що допомагають зберегти, нівелювати або посилити емотивну та експресивну функцію повідомлення. Здійснений перекладацький аналіз доводить, що у промовах жінок-політиків на противагу чоловікам-політикам міститься більша кількість лексико-стилістичних засобів мовлення. 
Жінки прагнуть зробити свої промови більш привабливими, яскравими, емоційними, правильно стилістично і граматично структурованими; тоді як мовлення чоловіків-політиків менш стилістично забарвлене, їхня головна мета - донести інформацію зрозумілою і простою мовою до свого електорату. До того ж проведене дослідження дало можливість зробити висновок, що не існує сталих універсальних методів відтворення лексико-стилістичних засобів реалізації стратегії театральності в політичних спічах як жінок, так і чоловіків, оскільки мова політики є динамічною, соціально зумовленою, реагує на зміни у суспільстві і його мовленнєвому процесі, а тому характеризується інноваційними змінами, розширенням та поповненням лексикону, що потребує аналітичного, комунікативно-прагматичного, синергетичного підходу до процесу перекладу політичного дискурсу.

\section{ЛIТЕРАТУРА}

1. Benoit W.L., Blaney J.R., Pier P.M. Campaign'96: A functional analysis of acclaiming, attacking, and defending. New York : Praeger. 1998. $342 \mathrm{p}$.

2. Маркович А.А. Аргументативная коммуникация. Методология исследования политического дискурса: Актуальные проблемы содержательного анализа общественно-политических текстов : сб. науч. трудов / под общ. ред. И.Ф. Ухвановой-Шмыговой. Минск : Белгосуниверситет. 1998. Вып. 1. С. 144-150.

3. Шестопал О.Г. Театральність як перцептивна категорія у контексті сучасних міждисциплінарних досліджень. Літературознавчі cmydiï. 2013. № 37(2). C. 436-442.

4. Маслова Ю.П. Особливості розвитку гендерних лінгвістичних досліджень в Україні та за кордоном. Наукові записки Національного університету «Острозька академія». Серія Філологічна. 2015. Вип 57. C. $100-105$.

5. Приходько Г.І. Лексико-граматичні інтенсифікатори оцінних структур. Науковий вісник ДДПУ імені І. Франка. 2017. С 154-158.

6. Клименко I.M., Зоренко I.C. Лексичні трансформації при передачі англійської політичної термінології українською мовою. Філологічні студіï. 2012. Вип 8. С. 84-90.

7. Charteris-Black J. Analysing Political Speeches: Rhetoric, Discourse and Metaphor. Palgrave Macmillan, 2013. 296 p.

8. Щеголєва Т.Л. Використання та переклад стилістичних засобів в американському політичному дискурсі. Вісник Черкаського університету. Серія: Філологічні науки. 2015. Вип. 7. С. 95-100. 


\section{ІЛЮСТРАТИВНИЙ МАТЕРІАЛ}

1. Candidates Answer CFR's Questions (Joe Biden). Council on Foreign Relations. URL: https://www.cfr.org/article/joe-biden.

2. Candidates Answer CFR's Questions (Joe Sestak). Council on Foreign Relations. URL: https://www.cfr.org/article/joe-sestak.

3. Candidates Answer CFR's Questions (Kamala Harris). Council on Foreign Relations. URL: https://www.cfr.org/article/kamala-harris.

4. Candidates Answer CFR's Questions (Pete Buttigieg). Council on Foreign Relations. URL: https://www.cfr.org/article/pete-buttigieg.

5. Candidates Answer CFR's Questions (Steve Bullock). Council on Foreign Relations. URL: https://www.cfr.org/article/steve-bullock.

6. Full interview: Sen. Kirsten Gillibrand on "Face the Nation". Face the Nation. URL: https://www.cbsnews.com/news/full-interview-sen-kirstengillibrand-on-face-the-nation-january-20-2019/.

7. Possible presidential candidate Steve Bullock on Trump, trade and tariffs. Today's TMJ4. URL: https://www.youtube.com/ watch? $\mathrm{v}=4 \mathrm{xmwfdbA0tE}$.

8. Tulsi Gabbard's Full Speech - Presidential Campaign Launch. URL: https://www.tulsi2020.com/press/2019-02-02-tulsi-gabbards-full-speechpresidential-campaign-launch.

\section{Information about the authors:} Medvid O. M.,

Candidate of Philological Sciences, Associate Professor, Associate Professor at the Department of Germanic Philology Sumy State University 2, Rymsky-Korsakov str., Sumy, 40000, Ukraine

Chihrin H. A., Master in Philology at the Department of Germanic Philology Sumy State University 2, Rymsky-Korsakov str., Sumy, 40000, Ukraine 